\title{
- Invited Review - Black soldier fly as feed ingredient for ruminants
}

\author{
Dewi Apri Astuti ${ }^{1}$ and Komang Gede Wiryawan ${ }^{1, *}$
}

* Corresponding Author:

Komang Gede Wiryawan

Tel: +62-251-8626213, Fax: +62-251-8626213,

E-mail: kgwiryawan61@gmail.com

${ }^{1}$ Department of Nutrition and Feed

Technology, Faculty of Animal Science, IPB

University, Bogor, 16680, Indonesia

\section{ORCID}

Dewi Apri Astuti

https://orcid.org/0000-0001-8655-9304

Komang Gede Wiryawan

https://orcid.org/0000-0002-0593-9653

Submitted Oct 9, 2021; Revised Nov 24, 2021; Accepted Dec 7, 2021

Parts of this review were presented at Animal Bioscience Forum 2021 on Animal Biosciences to Improve Animal Health and Production: Insect proteins for animals - current status, potentials and challenges (September 28-29, 2021), which was supported by Pathway Intermediates (http://www.pathwayintermediates.com).

\begin{abstract}
This paper is a review of some experiments using black soldier fly (BSF) and its by-product to explore their nutritional value, production potential in Indonesia and its application in the ration of ruminants. Evaluation on the effect of milk replacer, creep feed containing BSF, BSF frass and the possibility to use lactic acid bacteria from BSF as probiotics are presented. Utilization of BSF larvae in milk replacer as skim and cream milk substitute showed that there were similarity on physiological, hematological status and performance of goat kids compared to those offered goat milk or commercial milk replacer. In addition, BSF larvae can be used to substitute soybean meal in the creep feed for post weaning goat kids without any differences in weight gain and blood profiles. However, utilization of BSF frass in the fattening goat ration resulted lower digestibility of dry matter and organic matter due to the chitin content in the frass. Black soldier fly larvae grown on chicken manure harbour lactic acid bacteria (LAB) which have potential as probiotics for ruminants. In general, BSF larvae has potential as ingredient for milk replacer, creep feed, fattening ration, and source of LAB for probiotics.
\end{abstract}

Keywords: Black Soldier Fly; Creep Feed; Frass; Milk Replacer; Probiotic

\section{INTRODUCTION}

Increasing world population requires an increase of food production, including livestock production. Livestock products such as meat, milk, eggs as part of food production is the fastest growing agricultural sector. The dominant livestock types are pig with $112.33 \mathrm{MT}$, poultry 109.02 MT, and cattle, which includes beef and buffalo meat 67.99 MT representing $91.80 \%$ of meat production in the world [1]. Indonesia is the fourth most populated country in the world and also needs high livestock products especially from ruminants. Small ruminant animals such as goat and sheep are potential sources of ruminant meat, but the production and reproduction performances are still very low. To improve the animal production, it is necessary to improve feed quality offered to the animals.

Recently, there is a growing use of insects as feed ingredients due to their high nutritional content. One of well-known insect named black soldier fly (BSF) especially Hermetia illucens, has been more and more used commercially in feed because of easy rearing, high yield, rich nutritional value and the ability to utilize organic wastes. Black soldier fly larvae can consume substrate $25 \mathrm{mg}$ up to $500 \mathrm{mg}$ fresh matter per larvae per day to produce body length around $27 \mathrm{~mm}, 6 \mathrm{~mm}$ wide and weight $220 \mathrm{mg}$ at 14 days old [2]. The nutrient composition of BSF larvae reared with mixed organic wastes ranges from $42 \%$ to $47 \%$, $11.8 \%$ to $34.8 \%, 7 \%$ to $9 \%$, and $14.6 \%$ to $15.9 \%$ for crude protein $(\mathrm{CP})$, fat, crude fiber $(\mathrm{CF})$, and ash, respectively [3]. Meanwhile if BSF are reared on palm oil meal, they contain $43 \%$ CP , $19.51 \%$ fat, $12.27 \% \mathrm{CF}$ and $4.85 \%$ ash, also contain a variety of fatty acids and amino 
acids as presented in Tables 1 and 2 [4,5]. Based on the BSF nutrient content, they have great potential as a feed ingredient for ruminants, especially to substitute soybean meal, fish meal and antimicrobial growth promoters as they also contain antibacterial medium length chain fatty acids.

Black soldier fly larvae can grow well in harsh condition such as on food waste or animal manure, and some researchers reported that BSF larvae harbour many types of microorganisms including lactic acid bacteria (LAB) [6]. Therefore, it may be important to study the potential of those $\mathrm{LAB}$ as probiotics candidate to replace the use of antibiotic growth promoter especially for young ruminants. This article review describes the potential of BSF and its by-product as ingredients in milk replacer, creep feed, and growing ration of kids as well as the potential of LAB isolated from BSF larvae as probiotics for ruminants.

\section{THE POTENTIAL OF BSF PRODUCTION IN INDONESIA}

Indonesia is an archipelago and tropical country which is very suitable for BSF production. Black soldier fly needs intensive direct ultraviolet light from the sun for mating, laying and development as a larvae. Utilization of BSF in Indonesia

Table 1. Fatty acid composition of 15-day-old black soldier fly larvae reared on organic waste

\begin{tabular}{lcc}
\hline \multirow{2}{*}{ Parameters } & \multicolumn{2}{c}{ Black soldier fly } \\
\cline { 2 - 3 } & Raw & Steam \\
\hline Fat content (\%) & 38.09 & 27.49 \\
Saturated fatty acid (\%) & & \\
Capric acid (C10:0) & 0.84 & 0.81 \\
Lauric acid (C12:0) & 40.29 & 49.18 \\
Tridecanoic acid (C13:0) & 0.02 & 0.03 \\
Myristic acid (C14:0) & 6.76 & 8.09 \\
Pentadecanoic acid (C15:0) & 0.12 & 2.70 \\
Palmitic acid (C16:0) & 9.99 & 8.53 \\
Heptadecanoic acid (C17:0) & 0.11 & 0.19 \\
Stearic acid (C18:0) & 1.27 & 1.42 \\
Arachidic acid (C20:0) & 0.04 & 0.05 \\
Behenic acid (C22:0) & 0.02 & 0.04 \\
Unsaturated fatty acid (\%) & & \\
Myristoleic acid (C14:1) & 0.16 & 0.23 \\
Palmitoleic acid (C16:1) & 2.07 & 2.70 \\
Cis-10-Heptadecanoic acid (C17:1) & 0.00 & 0.24 \\
Elaidic acid (C18:2n9t) & 0.30 & 0.29 \\
Oleic acid (C18:1n9c) & 7.99 & 5.94 \\
Linolelaidic acid (C18:2n9t) & 0.00 & 1.41 \\
Linoleic acid (C18:2n6c) & 4.02 & 0.03 \\
v-Linolenic acid (C18:3n6) & 0.00 & 0.00 \\
Cis-11,14-Eicosedienoic acid (C20:2) & 0.02 & 0.03 \\
Cis-8,11,14-Eicosetrienoic acid (C20:3n6) & 0.03 & 0.02 \\
Total fatty acid (\%) & 74.04 & 79.41 \\
\hline Soure:Harystarni et (5) & &
\end{tabular}

Source: Harlystiarini et al [5]. started in 2005. According to data of Indonesian Ministry of Fisheries in 2021, there are more than 175 BSF farmers from west (Sumatra island) to east (Papua island) with average production rate of $100 \mathrm{~kg}$ per day. Most of them rear BSF using organic waste and the larvae are directly fed to their fish, local poultry while very few go to ruminant feed. Only a few in the BSF industry use palm oil meal to produce BSF as an export commodity. The leftover medium after it is used for BSF larvae growth, called frass and liquor can be used for organic fertilizer. The problem with a small scale production is the price. In Indonesia, the dry BSF price is still more expensive compared to imported soybean meal, fish meal or meat bone meal. Good manufacturing practice may reduce the BSF production cost.

\section{APLICATION OF BLACK SOLDIER FLY LARVAE IN RUMINANT RATIONS}

Black soldier fly is currently the most widely used insect in animal feed research due to its high nutritional value and cost effectiveness [7]. The demand for ruminant feed from forage and agricultural waste have been increasing every year. Originally, ruminants could survive with hay and forage, but in some cases they need additional feed or functional feed such as milk replacer for a new born, flushing diet to boost growth rate, and induce hormones during reproduction or special diet for recovering from stress. Black soldier fly with high essential amino acids, lauric acid as an antibacteria and LAB as probiotics has potential to be used as functional feed for ruminants. This statement is supported by previous study where some insects were used as potential feed ingredients for ruminants [8]. Fuctional feed is usually given for a short period to improve the condition according to the purpose of the supplementation.

The feed cost of ruminant industry usually contributes up

Table 2. Analyzed amino acids content of black soldier fly larvae reared on palm oil meal

\begin{tabular}{lc}
\hline Amino acid & Percent of total amino acid \\
\hline Histidine & 0.83 \\
Threonine & 1.40 \\
Arginine & 2.26 \\
Tyrosine & 2.83 \\
Methionine & 0.78 \\
Valine & 2.76 \\
Phenylalanine & 2.02 \\
Isoleucine & 2.17 \\
Leucine & 2.95 \\
Lysine & 2.37 \\
Serine & 1.45 \\
Glysine & 1.42 \\
Alanine & 2.47 \\
\hline
\end{tabular}

Source: Harlystiarini et al [5] 
to $40 \%$ to $60 \%$ of the production cost, and the proportion of protein accounts for over $15 \%$ of total feed cost [9]. Many kinds of protein feed sources such as legumes, grains and animal waste can be used as part of the ration. For an ecofriendly industry, there is a growing interest for using insects as a protein source in livestock, therefore there is an increasing use of BSF as a source of protein [10]. Some part of BSF products can be used for functional feed, such as dry BSF, oil, meal, frass, chitin and LAB from BSF larvae digestive tracts. The application of BSF and its by-products in ruminants has carried out over the last five years at the IPB University, Indonesia.

\section{Utilization of black soldier fly for milk replacer}

Milk replacer is formulated from high quality ingredients to provide the nutrient requirements for young animals. Milk replacer is usually given to the pre-weaning animals to replace the mother's milk which can be sold by the farmer. The quality of milk replacer should be more or less similar to the original milk, and the quality of milk replacer should contain $20 \%$ to $24 \%$ protein, $20 \%$ to $30 \%$ fat, $1 \%$ calcium and $0.8 \%$ phosphorous [11]. Most milk replacers are dry powders that have to be reconstituted to a liquid by mixing with warm water. Some formulas of milk replacer have been made containing source of protein from cricket meal for goat kids [12], gluten hydrolyzed for calves, and puffed corn or puffed full fat soybean for lambs. An experiment was designed to compare the effectiveness of goat milk, commercial milk replacer and BSF milk replacer on pre-weaning goat kids. The milk replacer was formulated containing $30 \%$ of fourteen days old BSF larvae meal mixed with egg flour, casein, full cream, wheat flour and some other minerals and vitamins. The milk replacer was offered to the goat kids 6 to 8 times a day until 5 weeks old and then continued until 8 week together with creep feed supplementation to imporve the rumen function development. The result showed that the dry matter and protein consumption of BSF milk replacer were the same compared to consumed goat milk, however fat consumption of BSF milk replacer was significantly higher $(\mathrm{p}<0.05)$ than kids consumed from goat milk (Table 3 ). Dry matter intake of goat kids fed milk replacer containing cricket meal is around $3 \%$ to $4 \%$ of body weight [12]. The palatability of new milk replacer with specific ingredients is important to be evaluated. Texture, smell and taste are some indicators which affect the palatability. According to Nutrient Research Council [13] goats are animals which are very sensitive to selecting feed (browsers). There is a decreasing BSF milk replacer intake compared to the commercial milk replacer and goat milk during the initial four weeks. The low initial intake of BSF milk replacer is due to the adaptation period and high fat content. Feeding with BSF milk replacer increased fat intake five times compared to goat milk. In this experiment, creep
Table 3. Dry matter and protein consumption of kids fed milk replacer containing black soldier fly larvae meal

\begin{tabular}{|c|c|c|c|c|}
\hline Consumption & Goat milk & Commercial MR & BSF MR & SEM \\
\hline \multicolumn{5}{|l|}{ Week 1 to 4 (MR) } \\
\hline Dry matter (g/d) & $151.0^{\mathrm{a}}$ & $208.0^{b}$ & $169.8^{\mathrm{a}}$ & 14.0 \\
\hline Protein $(\mathrm{g} / \mathrm{d})$ & 30.2 & 33.9 & 31.8 & 2.0 \\
\hline Fat $(\mathrm{g} / \mathrm{d})$ & $6.3^{\mathrm{a}}$ & $33.9^{b}$ & $33.8^{b}$ & 2.0 \\
\hline \multicolumn{5}{|l|}{ Week 5 to 8 (MR) } \\
\hline Dry matter (g/d) & $160.4^{\mathrm{a}}$ & $210.4^{b}$ & $172.0^{a}$ & 13.0 \\
\hline Protein $(\mathrm{g} / \mathrm{d})$ & 31.6 & 33.7 & 32.2 & 2.1 \\
\hline Fat $(\mathrm{g} / \mathrm{d})$ & $6.7^{a}$ & $33.7^{b}$ & $34.2^{b}$ & 2.5 \\
\hline \multicolumn{5}{|l|}{ Week 5 to 8 (CF) } \\
\hline Dry matter (g/d) & 93.7 & 121.1 & 84.9 & 41.0 \\
\hline Protein $(\mathrm{g} / \mathrm{d})$ & 15.2 & 19.7 & 13.8 & 6.7 \\
\hline Fat $(\mathrm{g} / \mathrm{d})$ & 1.8 & 2.4 & 1.7 & 0.4 \\
\hline \multicolumn{5}{|c|}{$\begin{array}{l}\text { MR, milk replacer; BSF, black soldier fly; SEM, standard error of mean; CF, } \\
\text { creep feed. } \\
a, b \text { Different superscript with lowercase in the same raw is significant } \\
\text { different at }(p<0.05) \text {. } \\
\text { Source: Astuti and Komalasari [4]. }\end{array}$} \\
\hline
\end{tabular}

feeding containing BSF larvae supplementation was started from fifth week of rearing, and it showed good palatability to pre-weaning kids. Milk replacer containing cricket meal improved the growth rate of kids similar to those offered with goat milk treatment [12]. The body weight gain of goat kids fed milk replacer containing BSF meal is the same as goat kids body weight gain fed with milk replacer containing cricket meal, which is around $157 \mathrm{~g} / \mathrm{d}$. The final body weight of weaning goats fed with goat milk is around $14 \mathrm{~kg}$, however weaning kids fed with milk replacer containing BSF have body weight around $12.5 \mathrm{~kg}$. The weaning weight of local Etawah crossbred with natural mating is around $11.1 \mathrm{~kg}$ [14]. Meanwhile $\mathrm{Lu}$ [15] stated that weaning weight depends on some factors such genetic, weaning age, health status, quality and quantity of mother's milk, litter size and feeding management. Data of the physiological status such as heart rate, respiration, and body temperature were the same in all treatments and in the range of normal condition. Milk replacer containing BSF larvae meal apparently has no negative effect on the physiological status of the goat kids. Studies using BSF larvae in the milk replacer show that feed conversion is 3.67 and higher than kids consumed goat milk (1.69). Energy and protein status are closely related to body weight gain and feed conversion ratio [16] .

\section{Utilization of black soldier fly larvae for creep feed} Creep feeding is a method of supplementing the diet of young livestock by offering feed to animals who are still nursing. Creep feeding is usually offered when lambs or kids are still nursing to provide additional nutrients to support animal growth [17]. Many studies used creep feed supplementation especially in calves to stimulate the rumen development and 
improve the growth rate. A trial was designed on post-weaning two-month-old Ettawah crossbred goats fed with creep feed for three months. The control diet formulated using $30 \%$ soybean meal without BSF larvae, meanwhile the other two creep feed treatments were formulated containing 15\% and $30 \%$ of BSF larvae, respectively. Data showed that the physiological and hematological status of growing goats were similar in all feeding treatments and it was in the normal range. The performance of those five-month-old growing kids was good with final body weight around $20 \mathrm{~kg}$. The growing goat kids fed cricket creep feed had higher average daily gain (123 g/d) [12] compared to the BSF creep feed treatment ( $89 \mathrm{~g} / \mathrm{d}$ ). It is reported that kids with intensive management could increase growth rate with consumption of $230 \mathrm{~g} / \mathrm{d}$ of creep feed containing $14 \% \mathrm{CP}$ based alfalfa [18]. Other experiments reported that with the supplementation of $18 \% \mathrm{CP}$ creep feed, the consumption is around $152 \mathrm{~g} / \mathrm{d}$ and no difference in weight gain [19]. Based on Beesigamukama et al [20] requirement for growing kids with $150 \mathrm{~g} / \mathrm{d}$ weight gain needed $4.81 \%$ dry matter intake of body weight, $86 \mathrm{~g} / \mathrm{d}$ of protein intake and $0.43 \mathrm{~kg} / \mathrm{d}$ of total digestible nutrient (TDN). Important variable that affects the performance of kids is not only the quality of ration but also the amount of feed intake. Insects with high protein and fat content show potential to be used in a creep feeding program. The best insects with high essential amino acids content, such as BSF, can potentially be used in creep feed.

Utilization of frass black soldier fly in the growing goat ration

Frass is the by-product of the larval meal industry that includes larval waste, exoskeleton sheds and residual feed ingredients. The quality of frass depends on the quality of medium and the amount of chitin content. In some reasearch which used organic waste medium, the frass contained around 15\% $\mathrm{CP}$ and $25 \% \mathrm{CF}$ with low TDN value. Information regarding BSF frass utilization for ruminant ration is still very rare. Frass mainly goes to the organic farm as a good quality fertilizer [21] or it is used for protein source in catfish [22]. Based on the nutrient quality of frass, it is possible to use it as an ingredient for ruminants. Black soldier fly frass from palm oil meal medium contains 19\% CP, $21 \%$ CF and $68 \%$ TDN, so it can be used as protein source or even for fibre source for ruminants.

An experiment was done in our laboratory using frass derived from BSF leftover medium was compared with the use of commercial concentrate on growing male Ettawah goats. The ration was formulated containing 30\% BSF frass from palm oil meal medium as a concentrate diet with $14 \% \mathrm{CP}$ and $68 \% \mathrm{TDN}$, whereas the commercial concentrate was formulated in the same quality. Data showed that there were no significant differences of nutrient intake in both treatments, meanwhile the digestibility of dry matter, organic matter, nitrogen free extract, and TDN were significantly lower $(\mathrm{p}<0.05)$ compared to the commercial diet (Table 4). This condition may be due to the high content of undigested fibre and chitin in frass. Data from the in vivo experiment showed similar results as those of the in vitro experiment.

\section{Potential of lactic acid bacteria from black soldier fly larvae as probiotics in ruminants}

Probiotics are defined as live microorganisms, providing health benefits for the host, when they are administered in adequate amounts FAO/WHO [23]. Lactic acid bacteria are commonly used as probiotics to replace antibiotic growth promoters against pathogenic bacteria due to their production of organic acids, hydrogen peroxide, and bacteriocins [24-26]. The application of LAB probiotics in young ruminants may reduce the incidence of diarrhea as well as improve body weight gain and feed efficiency. Holstein calves supplemented with $L$. acidophilus 27SC had significantly higher colony counts of lactobacilli in feces compared to calves fed a control diet. As a result, calves fed $L$. acidophilus 27SC showed significant differences in scour index during weeks 5,7 , and 8 compared with calves fed a control diet and, during weeks 7 and 8 compared with calves fed a mixed lactobacilli diet [27]. The effects of oral administration lactic acid producing bacteria of Bifidobacterium pseudolongum or L. acidophilus on newborn calves were also investigated [28]. Oral administration of the two types of LAB improved body weight gain and feed efficiency, and reduced frequencies of diarrheacompared to calves that did not receive LAB. In another investigation using the addition of $L$. mucosae and cell-free supernatant during the in vitro fermentation of dried brewers grain increased the volatile fatty acids production, but had no effect on dry matter and organic matter digestibility. Furthermore, the addition of $L$. mucosae can also increase the total bacterial population but have no significant effect on the total microbial diversity [29].

Table 4. Nutrient digestibility of growing goat fed black soldier fly frass

\begin{tabular}{lccc}
\hline Nutrient digestibility & $\begin{array}{c}\text { Concentrate } \\
\text { commercial }\end{array}$ & $\begin{array}{c}\text { Concentrate } \\
\text { BSF frass }\end{array}$ & SEM \\
\hline Dry matter (\%) & $74.1^{\mathrm{b}}$ & $66.5^{\mathrm{a}}$ & 1.9 \\
Organic matter (\%) & $75.7^{\mathrm{b}}$ & $67.4^{\mathrm{a}}$ & 1.8 \\
Crude protein (\%) & 69.5 & 66.5 & 2.6 \\
Fat (\%) & 92.1 & 91.2 & 2.3 \\
Crude fibre (\%) & 56.0 & 50.0 & 6.5 \\
NFE (\%) & $82.0^{\mathrm{b}}$ & $73.7^{\mathrm{a}}$ & 2.1 \\
TDN (\%) & $80.0^{\mathrm{b}}$ & $74.4^{\mathrm{a}}$ & 1.0 \\
\hline
\end{tabular}

BSF, black soldier fly; SEM, standard error of mean; NFE, nitrogen free extract; TDN, total digestible nutrients.

${ }^{a, b}$ Different superscript with lowercase in the same raw is significant different at $(p<0.05)$. 
Table 5. pH of lactic acid bacteria (isolated from black soldier fly) after 24 hours incubation in De Man, Rogosa and Sharpe medium

\begin{tabular}{|c|c|c|c|c|c|c|c|c|c|c|c|c|c|}
\hline Isolate & A1 & A2 & A3 & A4 & A5 & A6 & A7 & A8 & A9 & A10 & A11 & A12 & A13 \\
\hline $\mathrm{pH}$ & 4.5 & 4.6 & 4.5 & 4.6 & 4.6 & 4.6 & 4.5 & 4.6 & 4.6 & 4.6 & 4.6 & 4.4 & 4.6 \\
\hline
\end{tabular}

Lactic acid bacteria can be isolated from a different variety of sources such as soil, flowers, fruits, fermented foods, and animal digestive tracks. Recently, there is a fast growing interest on the use of insects especially BSF (Hermetia illucens) larvae as animal feed due to its high protein and lipids content. Black soldier fly larvae convert different kinds of organic wastes such as food waste, and animal manure [30,31]. Black soldier fly larvae can survive under harsh conditions, so they may possess some good bacteria in their intestines that can compete with pathogenic bacteria. Therefore, research has been conducted in our laboratory to isolate and characterize LAB that can be used as a probiotics candidate in ruminant animals.

The results of our experiment showed that there were 13 $\mathrm{LAB}$ isolates which have different colors and morphologies of colonies and have characteristics of gram positive, catalase negative, and cocci cell morphology. All isolates produced organic acids as shown by low $\mathrm{pH}$ (ranged from 4.4 to 4.6) after 24 hours incubation in the De Man, Rogosa, and Sharpe (MRS) medium (Table 5). In addition, all isolates were able to inhibit the growth of Escherichia coli (E. coli) as shown by the clearing zone produced using agar well diffusion method [32]. Figure 1 shows the diameter of the clearing zone of $E$. coli treated with cell-free supernatant of isolates. The diameter of clearing zone ranged from $6.18 \mathrm{~mm}$ to $10.98 \mathrm{~mm}$. The isolates A4 and A5 had significantly higher $(\mathrm{p}<0.05)$ inhibi- tory activity on E. coli growth compared to the other isolates. The inhibitory activity of the LAB isolates on $E$. coli in this experiment was lower compared to those LAB isolated from asam durian [33]. Production of organic acids and the ability of LAB in inhibiting the growth of pathogenic bacteria such as $E$. coli is an important factor in selecting probiotic candidates because the probiotics should be able to compete and eliminate the pathogenic bacteria in the intestines. However, it is not clear yet whether the inhibition of $E$. coli growth is only caused by organic acids or there may be other antipathogenic compounds such as bacteriocin produced. Further study is required to evaluate the production of bacteriocin.

Three isoltaes (A5, A11, and A13) which have different colony morphology and diameter of clearing zone were further tested for their ability to survive in intestinal conditions such as different $\mathrm{pH}$ [34] and bile salt $0.5 \%$ [35]. The results show that the three isolates were able to survive at three different $\mathrm{pH}(2,4$, and 6) (Table 6). The survival rate of LAB isolates at $\mathrm{pH} 2,4$, and 6 ranged from $73.41 \%$ to $77.13 \%$, $80.55 \%$ to $86.28 \%$, and, $81.23 \%$ to $94.69 \%$, respectively. The survival rate of the isolate A5 was consistently higher $(\mathrm{p}<0.05)$ than that of isolate $\mathrm{A} 13$ in all $\mathrm{pH}$ conditions and was higher $(\mathrm{p}<0.05)$ than that of isolate $\mathrm{A} 11$ at $\mathrm{pH} 4$ and $\mathrm{pH}$ 6. Isolate A5 also had higher survival rate at $\mathrm{pH} 2$ compared to the survival rate of LAB isolated from soil reported by [36], but it was lower than the survival rate of LAB isolated from asam

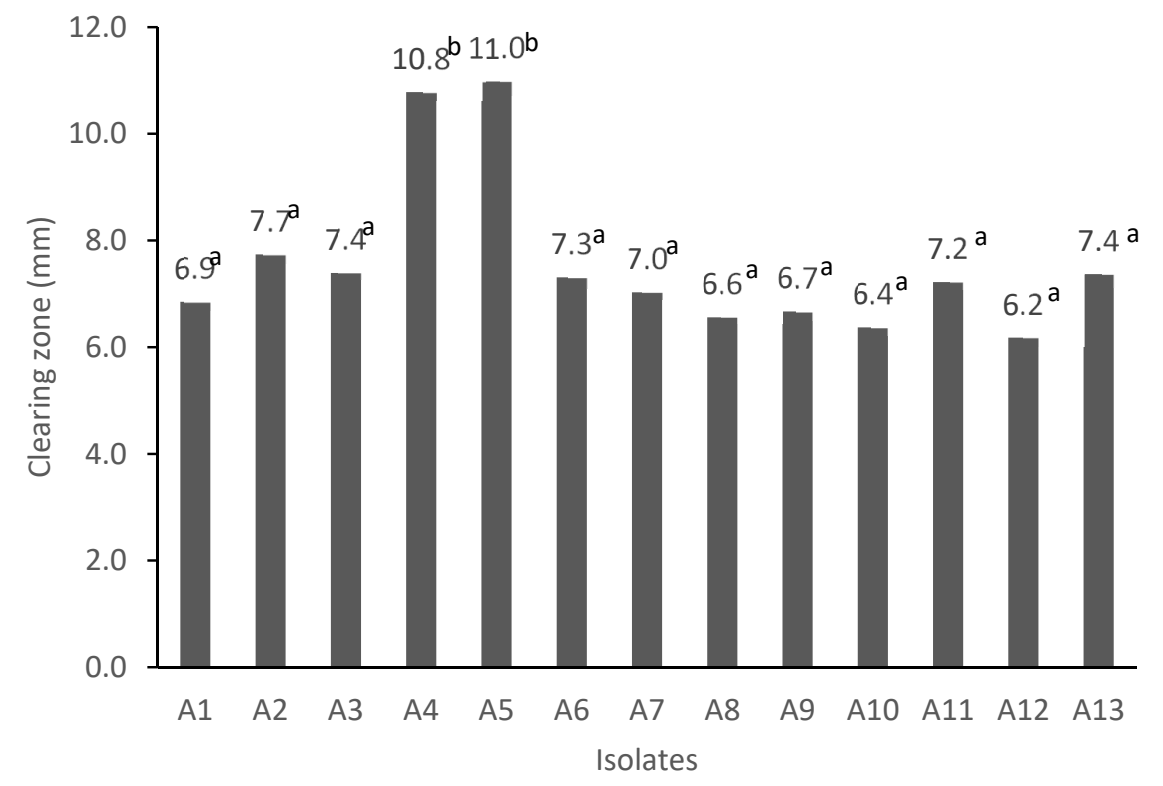

Figure 1. Clearing zone growth inhibition of Escherichia coli by lactic acid bacteria isolated from black soldier fly larvae. ${ }^{\mathrm{a}, \mathrm{b}}$ Different superscript means significant different $(p<0.05)$. 
Table 6. Percentage of lactic acid bacteria (isolated from black soldier fly larvae) survival at different $\mathrm{pH}$ and $0.5 \%$ bile salts

\begin{tabular}{lcccc}
\hline \multirow{2}{*}{ Isolates } & \multicolumn{4}{c}{ Survival (\%) } \\
\cline { 2 - 5 } & $\mathbf{p H ~ 2}$ & $\mathbf{p H ~ 4}$ & $\mathbf{p H ~ 6}$ & Bile salts $\mathbf{0 . 5} \%$ \\
\hline A13 & $73.4^{\mathrm{a}}$ & $82.0^{\mathrm{a}}$ & $81.2^{\mathrm{a}}$ & 76.8 \\
A11 & $77.1^{\mathrm{b}}$ & $80.6^{\mathrm{a}}$ & $93.0^{\mathrm{b}}$ & 78.5 \\
A5 & $75.8^{\mathrm{b}}$ & $86.3^{\mathrm{b}}$ & $94.7^{\mathrm{b}}$ & 75.4 \\
SEM & 1.1 & 1.0 & 4.2 & 1.3 \\
p-value & 0.01 & 0.05 & $<0.01$ & 0.27 \\
\hline
\end{tabular}

SEM, standard error of mean.

$a, b$ Different superscript in the same column is significant difference at $(p<0.05)$.

durian [33]. The LAB can survive in the acid condition due to the ability of LAB to protect membrane damages from low extracellular $\mathrm{pH}$ [37]. Meanwhile, the survival rate of the three $\mathrm{LAB}$ isolates on $0.5 \%$ bile salts ranged from $75.35 \%$ to $78.53 \%$ and there were no significant different amongst the three isolates (Table 6).

One important criteria for selecting $\mathrm{LAB}$ as probiotic candidates is the ability of the bacteria to adhere on the mucosal surface of the intestines. It means that the bacteria should be able to recognize the receptor availbale on the surface of intestines and form biofilm to colonize the intestines and compete with pathogenic bacteria. The method used to evaluate the adherence of $\mathrm{LAB}$ on the intestines is the stainless steel method [37]. The results showed that the three LAB isolates were able to adhere to the surface of stainless steel. The percentage of adhesion was ranged from $57.08 \%$ to $60.04 \%$ and there was no significant different amongst the three isolates (Table 7). The percentage of isolates adhering in this experiment was lower compared to that reported by Dewanti and Wong [38], who found that the percentage of adhesion was between $81 \%$ to $94 \%$, but it was higher to that reported by Babot et al [39]. The differences in adhesion abilities of strains are specific and depend on physiology of cell and composition of cell wall [40].

\section{CONCLUSION}

Black soldier fly larvae harvested on day 15th has potential to be used as an ingredient in the ruminant rations. The milk replacer and creep feed containing BSF larvae, and also con-

Table 7. Number and percentage of lactic acid bacteria (isolated from black soldier fly larvae) adhesion on the surface of stainless steel

\begin{tabular}{|c|c|c|c|}
\hline Isolates & $\begin{array}{l}\text { Initial population } \\
\left(\log \text { cell } / \mathrm{cm}^{2}\right)\end{array}$ & $\begin{array}{l}\text { Cell adhesion } \\
\left(\log \text { cell/ } \mathrm{cm}^{2}\right)\end{array}$ & $\begin{array}{c}\text { Percentage of } \\
\text { adhesion }\end{array}$ \\
\hline A13 & 8.96 & 5.38 & 60.04 \\
\hline A11 & 8.90 & 5.08 & 57.08 \\
\hline A5 & 8.81 & 5.15 & 58.46 \\
\hline
\end{tabular}

centrate containing BSF frass could improve performance of pre- and post-weaning and growing goats. BSF larvae grown on chicken manure harbor LAB which are potentially probiotic candidates.

\section{CONFLICT OF INTEREST}

We certify that there is no conflict of interest with any financial organization regarding the material discussed in the manuscript.

\section{FUNDING}

The authors received no financial support for this article.

\section{ACKNOWLEDGMENTS}

The authors would like to thanks our students Rentia, Claudia, Erik and Irvan for helping the commencement of the experiments.

\section{REFERENCES}

1. FAOSTAT. Statistics Division. Rome, Italy: Food and Agriculture Organization of the United Nations; 2013 [cited 2021 Sept 25]. Available from: http://www.fao.org/faostat/ en/\#data/QL

2. Park HH. Black soldier fly larvae manual. Amherst, MA, USA: University of Massachusetts Amherst; 2016.

3. Kroeckel S, Harjes AGE, Roth I, et al. When a turbot catches a fly: evaluation of a prepupae meal of black soldier fly (Hermetia illucens) as fish meal substitute - growth performance and chitin degradation in juvenile turbot (Psetta maxima). Aquaculture 2012;364-365:345-52. https://doi.org/10.1016/j. aquaculture.2012.08.041

4. Astuti DA, Komalasari K. Feed and animal nutrition: insect as animal feed. In: Proceedings of the 3rd International Conference Tropical Animal Production for Food Security. IOP Conf Ser Earth and Environ Sci 2020;465:012002. https:// doi.org/10.1088/1755-1315/465/1/012002

5. Harlystiarini R, Mutia IWT, Wibawan, Astuti DA. In vitro antibacterial activity of black soldier fly (Hermetia Illucens) larva extracts against gram-negative bacteria. Buletin Peternakan 2019;43:125-9. https://doi.org/10.21059/buletin peternak.v43i2.42833

6. Wynants E, Frooninckx L, Crauwels S, et al. Assessing the microbiota of black soldier fly larvae (Hermetia illucens) reared on organic waste streams on four different locations at laboratory and arge scale. Microb Ecol 2019;77:913-30. https://doi.org/10.1007/s00248-018-1286-x

7. Dabbou S, Gai F, Biasato I, et al. Black soldier fly defatted meal as a dietary protein source for broiler chickens: effects 
on growth performance, blood traits, gut morphology and histological features. J Anim Sci Biotechnol 2018;9:49. https:// doi.org/10.1186/s40104-018-0266-9

8. Jayanegara A, Yantina N, Novandri B, et al. Evaluation of some insects as potential feed ingredients for ruminants: chemical composition, in vitro rumen fermentation and methane emissions. J Indonesian Trop Anim Agric 2017; 42:247-54. https://doi.org/10.14710/jitaa.42.4.247-254

9. Lawrence JD, Mintert J, Anderson JD, Anderson DP. Feed grains and livestock: impacts on meat supplies and prices. Choices 2008;23:11-5.

10. Van Huis A, Itterbeeck VJ, Klunder H, et al. Edible insects future prospects for food and feed security. Rome, Italy: FAO Forestry Paper; 2013. No.171.

11. [FAO] Food and Agricultural Organization of United Nation (IT). Rearing young ruminants on milk replacers and starter feeds. FAO Animal Production and Health Manual. Rome, Italy: FAO of the United Nation; 2011.

12. Astuti DA, Anggraeny A, Khotijah L, et al. Performance, physiological status, and rumen fermentation profiles of pre- and post-weaning goat kids fed cricket meal as a protein source. Trop Anim Sci J 2019;42:145-51. https://doi.org/10. 5398/tasj.2019.42.2.145

13. Nutrient Research Council (NRC). Nutrient requirements of small ruminants. Washington DC, USA: The National Academies Press; 2007.

14. Sutama IK, Putu IG, Wodzisca-Tomaszewska M. Improvement in small ruminant productivity through more efficient reproduction. In: Improvement in Small Ruminant Production in The Humid Tropics. Surakarta, Indonesia: Sebelas Maret University Press; 1993. pp. 191-266.

15.Lu CD. Boer goat production: Progress and Persective. In: Proceedings of International Conference on Boer Goats; 2001 Oct 20-24; Anshun, China. pp. 1-11. https://www. researchgate.net/publication/237812985_Boer_goat_ production_progress_and_perspective

16. McDonald P, Erwards RA, Greenhalgh, et al. Animal nutrition Ed 7th. Edinburgh, UK: Pearson Publication; 2010.

17. Eversole DE. Creep feeding beef calves. Virginia Cooperative Extension. Blacksburg, VA, USA: Virginia Tech Retrived; 2013. pp. 6-21.

18. Htoo NN, Khaing AT, Abba Y, et al. Enhancement of growth performance in pre-weaning suckling Boer kids supplemented with creep feed containing alfalfa. Vet World 2015;8:718-22. https://doi.org/10.14202/ vetworld.2015.718-722

19. Goetsch AL, Detweiler G, Sahlu T. A note on the effects of preweaning concentrate supplementation on performance of meat goats. J Appl Anim Res 2002;21:25-34. https://doi. org/10.1080/09712119.2002.9706354

20.Nutrient Research Council (NRC). Nutrient requirements of small ruminants. Washington DC, USA: The National Academies Press; 2007.
21. Beesigamukama D, Mochoge B, Nicholas KK, et al. Exploring black soldier fly frass as novel fertilizer for improved growth, yield, and nitrogen use efficiency of maize under field conditions. Front Plant Sci 2020;11:574592. https://doi.org/10. 3389/fpls.2020.574592

22. Mediha YA, Rashida E, Benjamin HB. Nutritional value of frass from black soldier fly larvae, Hermetia illucens, in a channel catfish, Ictalurus punctatus, diet. Aquac Nutr 2020; 26:812-9. https://doi.org/10.1111/anu.13040

23. FAO/WHO. Guidelines for the evaluation of probiotics in food. Rome, Italy: FAO; 2002. Available from: https://www. who.int/foodsafety/fs_management/en/probiotic_guidelines. pdf

24. Reis JA, Paula AT, Casarotti SN, et al. Lactic acid bacteria antimicrobial compounds: Characteristics and applications. Food Eng Rev 2012;4:124-40. https://doi.org/10.1007/s12393012-9051-2

25. Ricci A, Bernini V, Maoloni A, et al. Vegetable by-product lacto-fermentation as a new source of antimicrobial compounds. Microorganisms 2019;7:607. https://doi.org/10.3390/ microorganisms7120607

26. Astuti WD, Wiryawan KG, Wina E, Widyastuti Y, Suharti S, Ridwan R. Effects of selected Lactobacillus plantarum as probiotic on in vitro ruminal fermentation and microbial population. Pak J Nutr 2018;17:131-9. http://doi.org/10.3923/ pjn.2018.131.139

27. Abu-Tarboush HM, Al-Saiady MY, Keir El-Din AH. Evaluation of diet containing lactobacilli on performance, fecal coliform, and lactobacilli of young dairy calves. Anim Feed Sci Technol 1996;57:39-49. https://doi.org/10.1016/0377-8401(95)00850-0

28. Abe F, Ishibashi N, and Shimamura S. Effect of administration of bifidobacteria and lactic acid bacteria to newborn calves and piglets. J Dairy Sci 1995;78:2838-46. https://doi.org/10. 3168/jds.S0022-0302(95)76914-4

29. Soriano AP, Mamuad LL, Seon-Ho K, et al. Effect of Lactobacillus mucosae on in vitro rumen fermentation characteristics of dried brewers grain, methane production and bacterial diversity. Asian-Australas J Anim Sci 2014;27:1562-70. https:// doi.org/10.5713/ajas.2014.14517

30. Nyakeri EM, Ogola HJO, Ayieko MA, Amimo FA. Valorisation of organic waste material: growth performance of wild black soldier fly larvae (Hermetia illucens) reared on different organic wastes. J Insects Food Feed 2017;3:193-202. https:// doi.org/10.3920/JIFF2017.0004

31. Barragán-Fonseca K, Pineda-Mejia J, Dicke M, van Loon JJA. Performance of the black soldier fly (Diptera: Stratiomyidae) on vegetable residue-based diets formulated based on protein and carbohydrate contents. J Econ Entomol 2018;111:267683. https://doi.org/10.1093/jee/toy270

32. Klose V, Bayer K, Bruckbeck R, Schatzmayr G, Loibner AP. In vitro antagonistic activities of animal intestinal strains against swine-associated pathogens. Vet Microbiol 2010; 
144:515-21. https://doi.org/10.1016/j.vetmic.2010.02.025

33.Putri A, Wiryawan KG, Toharmat T, Suharti S. Potential of lactic acid bacteria from asam durian as a probiotic candidate for chicken. IOP Conf. Series: Materials Science and Engineering 2019;546:062019. https://doi.org/10.1088/1757-899X/546/ $6 / 062019$

34. Messaoudi S, Madi A, Prévost $\mathrm{H}$, et al. In vitro evaluation of the probiotic potential of Lactobacillus salivarius SMXD51. Anaerobe 2012;18:584-9. https://doi.org/10.1016/j.anaerobe. 2012.10.004

35. Bao Y, Zhang Y, Zhang Y, et al. Screening of potential probiotic properties of Lactobacillus fermentum isolated from traditional dairy products. Food Control 2010;21:695-701. https://doi.org/10.1016/j.foodcont.2009.10.010

36. Hamida F, Wiryawan KG, Meryandini A. Selection of lactic acid bacteria as probiotic candidate for chicken. Media Peternakan 2015;38:138-44. https://doi.org/10.5398/medpet.2015. 38.2.138
37. Begley M, Hill C, Gahan CGM. Bile salt hydrolase activity in probiotics. Appl Environ Microb 2006;72:1729-38. https:// doi.org/10.1128/AEM.72.3.1729-1738.2006

38. Dewanti R, Wong ACL. Influence of culture conditions on biofilm formation by Escherichia coli O157:H7. Int J Food Microbiol 1995;26:147-64. https://doi.org/10.1016/01681605(94)00103-d

39. Babot JD, Arganaz-Martinez E, Saavedra L, Apella MC, Chaia AP. Selection of indigenous lactic acid bacteria to reinforce the intestinal microbiota of newly hatched chicken - relevance of in vitro and ex vivo methods for strains characterization. Res Vet Sci 2014;97:8-17. https://doi.org/10. 1016/j.rvsc.2014.06.001

40. Ranadheera CS, Evans CA, Adams MC, Baines SK. In vitro analysis of gastrointestinal tolerance and intestinal cell adhesion of probiotics in goat's milk ice cream and yogurt. Food Res Int 2012;49:619-25. https://doi.org/10.1016/j. foodres.2012.09.007 